\title{
Higher education in laser applications
}

\author{
Vadim Veiko, Mikhail Libenson
}

Vadim P. Veiko, Mikhail N. Libenson, "Higher education in laser applications,"

Proc. SPIE 1603, Education in Optics, (1 March 1992); doi: 10.1117/12.57853 


\title{
HIGHER EDUCATION \\ IN LASER APPLICATIONS
}

\author{
Vadia P. Veiko, Michael N. Libenson \\ St. Petersburg Institute of Fine Mechanics and Optics \\ USSR, 197101 St.Petersburg, Sablinskaya 14
}

\section{ABSTRACT}

Froblems of special high education in laser applications are discussed. Education in the field of laser techniques, applied optics, interaction of laser radiation with matter 15 imperative and in demand for many application areas.

At laser technology chair (st.f IFMO), besides laser technology, the basic education in three subject areas of laser applications is given: lasers in environment studies, laser medicine and laser safety.

The education in laser technology is considered in more detail. The information about optical systems for technological lasers, laser techniques and physics, and laser beam interaction with solids are given in theoretical courses, in laboratories of lasers in microelectronics and lasers in optics technology and in the practical classes.

This education offers an opportunity for professional activity in RaD and production in many fields of laser applications.

\section{INTRODUCTION}

Now it 15 well established that the focus of attention has moved from the laser physics to the laser applications. It is due to the fact is that the laser application market is expanding with the rate of approximately $25 \%$ per year for the last 8 - 10 years, and most of forecasts give the same rate to the end of the century.

It puts a task before high school to teach students in this field. This task is not so easy, as it could be seen from outside. Frimarily the problem is in optimal combination of the knowledge in laser fields with the and knowledge in the field of application, such as technology (welding; hardening, microelectronics), medicine, environment studies, etc:

It 15 possible to solve this problem in two ways $(f i g 1)$. The first one is to bulld a big tower of the little bricks from every subject area.

The second one is to give a good basic knowledge. In any case the time of education 15 the same.

But following the first way one can recelve only one kind of education frults because it is very hard to change the specialty. The second way 15 to give on opportunities to be more flexible, and permit one to hope tor the different kinds of results depending on the requirements of life. 


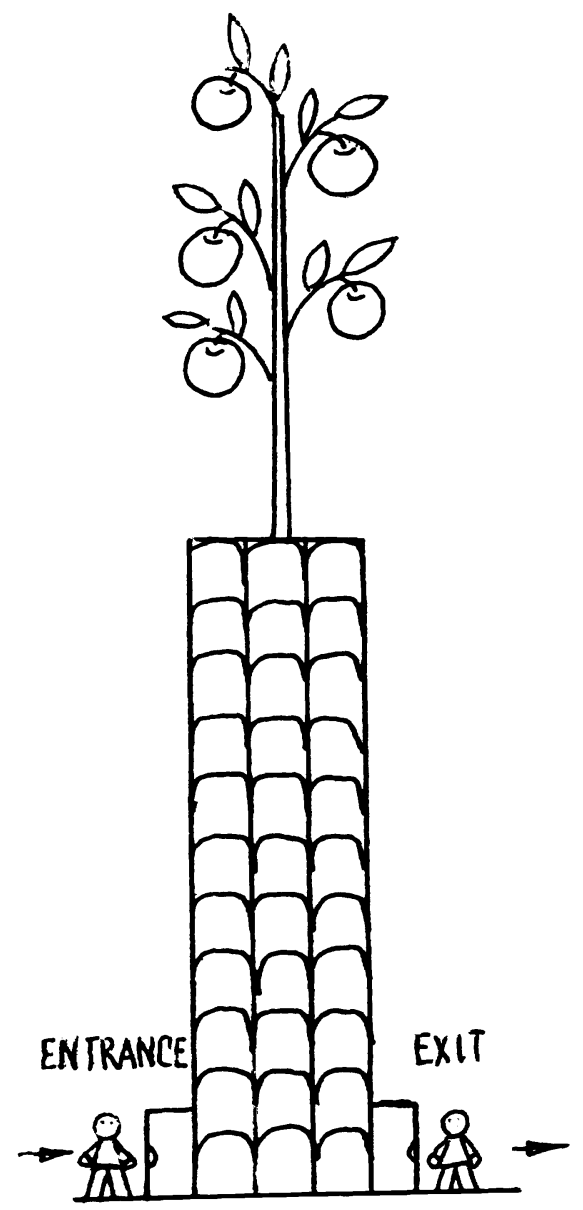

First way

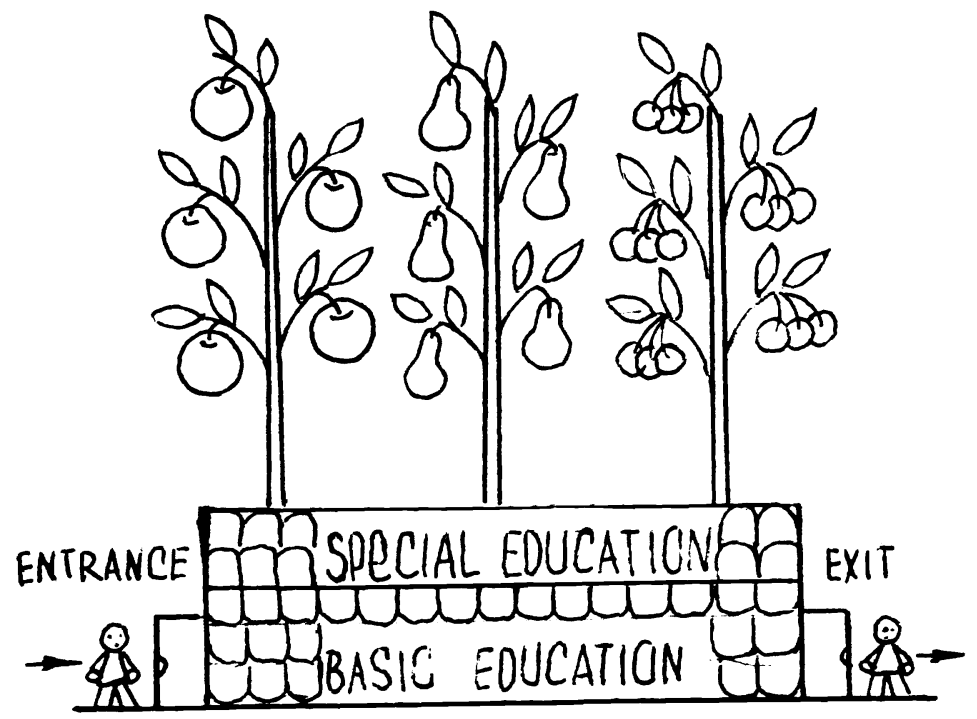

Second way

EXIT

$\int_{\text {ENTER }}$ F (irst way)dt $=\int_{\text {ENTER }}$ S(econd way $) d T=T_{\text {education }}$ 
Here we oresent the experience of laser technology chair ot St. PIFMO. This chair was founded in 1987 on the basis of the problem laboratory, working from 1965. Of course, in our institute we can teach only engineers and physicists in optics.

And here is the second problem: optimal combination of basic and special subjects.

Naturally, higher university education in laser applications include the general and the special parts. General part contains a number of physical and engineering courses.

Education in laser applications involves the knowledges in mathematical physics, physical optics; laser techniques and applied optics which is given within general courses (see table.1).

\section{GENERAL STRUCTURE OF SPECIAL HIGH EDUCATION IN LASER APPLICATIONS AT LASER TECHNOLOGY (LT) CHAIR OF LIFMO.}

At laser technology chair (St.FIFMo), in addition to laser technology the basic education in three other subjects of laser applications is given: laser medicine, laser environment studies and laser safety.

Four basic and three optional courses are given every year (Table 1 ).

Certainly each subject, 1 . e. technology, medicine, environment; safety is supported by all basic courses. They nave many common $155 u e s$ in interaction of radiation with matter, in optics, iaser equipment and processes contral.

Students have laboratory training in every subject. Some of them are located in the premises of production facilities (technology) institutes (environment) and clinics (medicine).

Theoretical seminars are held under items $1,2,3$. There by students acquire practical skills in quantitative estimates of laser-matter interaction models and selection of machining processes.

We consider the laser technology education in more detail.

\section{LASER TECHNOLOGY HIGHER EDUCATION}

This subject 1 s the core one at the LT char of St.PIFMu and it is supported by research laboratory.

The structure of basic courses for laser technology education is presented below. 
Table.1

STRUCTURE OF SPECIAL COURSES AT LASER TECHNOLOGY CHAIR

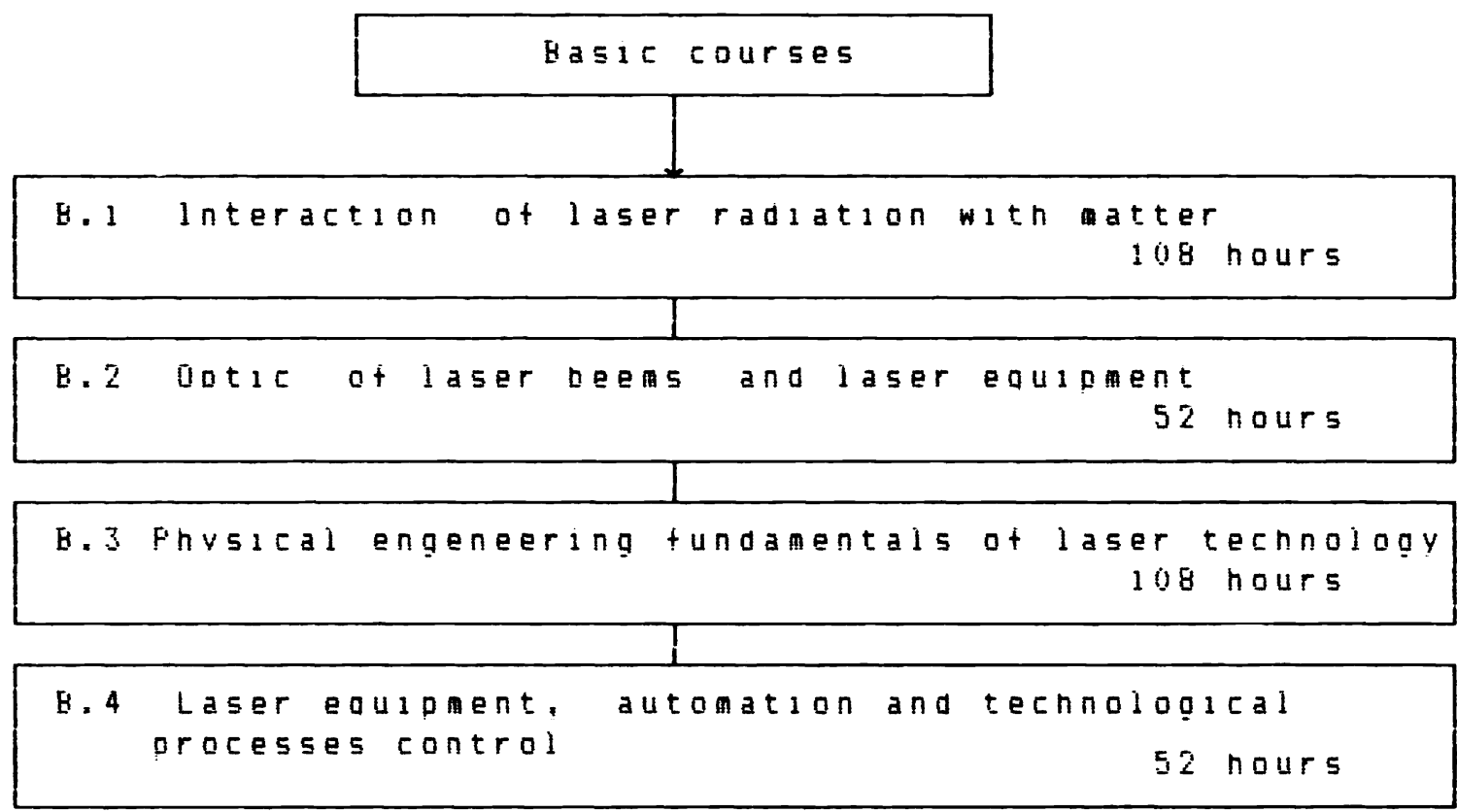

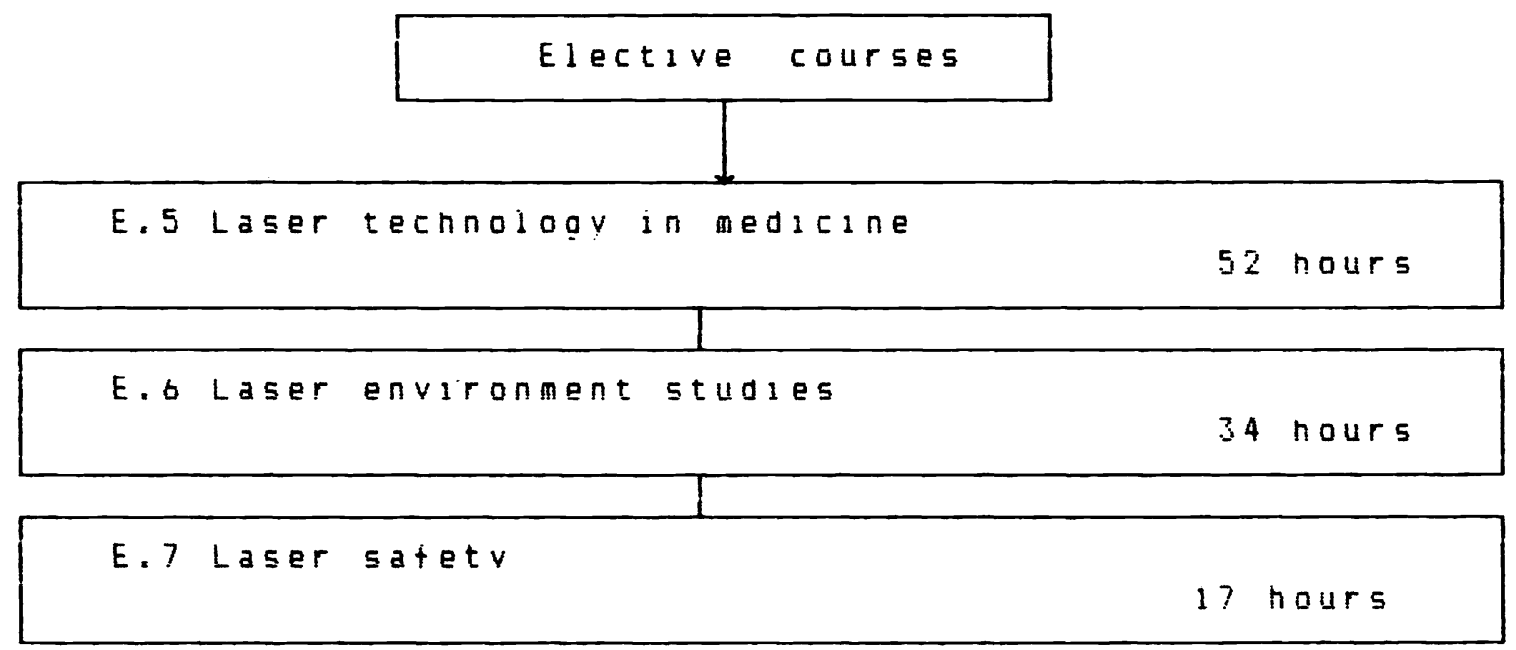

3.1 B. 1 INTERACTION DF LASEF RADIATION WITH MATTER

The interaction of laser radjation with various substances is the basic course for oroad education in each laser apolication. lt contains the problens of laser interaction with absorbing solids (for technolony), with biological tissues (for biomedicine), with light - scattering media - air and water ffor environment). Table 2 illustrate the structure of this course. 
Part 1. is devoted to detalled consideration of the thermal model of laser action on metals and absorbing semiconductors. basic bnowledoe is presented on the oftical properties of these media and optical processes resulting in light absorption and heat production. Thermal - physical aspects of laser heating are thoroughly outlined. Much attention is fayed to acquaintance with basic physical and chemical processes accompanying heating: emission, diffusion chemical and thermomechanical processes phase transitions. Laser - induced modifications in optical materials properties are examined as well as the complex nonlinear modes of laser heating due to those modifications in case of reciprocal relations between optical and thermal processes substantially affecting the kinetics at temperature variation. The probiems of basic thermal mechanisms of laser damage of bulk materials and thin films, and the domains of their realization are outlined. special attention is brought to laser action on a surtace and the specific processes occurring in this case: generation of surface electromangetic excitations and periodic structures forming.

Part 2. covers certain problens of laser interaction with weakly absorbing materials. Basic concepts are presented of light absorption mechanisms and optical breakdown of transparent media chomogeneous and containing optical inhomogeneities). Specitic features of high - power radiation effects on biological objects are discussed. In view of rapid development of ultrashort laser pulses techniques and studies of substances behavior in ultra strong light fields, a number of nonequlibrium laser induced processes in condensed matter are considered.

\subsection{B.2 OPTICS OF LASER BEAMS AND LASER EQUIPMENT}

The content of this course 15 illustrated by table 3.

Part one is devoted to methods of calculation of basic optical schemes for laser beams. The following topics are given: calculations for single mode and multimode lasers, the comparison of several calculation methods from the coherence of radiation point of view, the calculation and design of some special optical systems; scanning, fiber optics etc. All this part is devoted to the optical systens for high power laser beans. In the second part the additional optical systems for laser equipment are considered. In this part the methods of calculation and design for non - laser sources, non - coherent beams are given. But it is very important for creation of laser equipment for technology, medicine, etc. 
Table. 2

Basic sections of the course

"LASEF - MATTEF INTEFACTION IN "LASER TECHNOLDGY"

SFECIALITY

PAFT 1. LASER ACTION ON ABSUREING MEDIA

Liont absorbtion and heat oroduction in nontransoarent materials

Materials heating by high-oower radiation

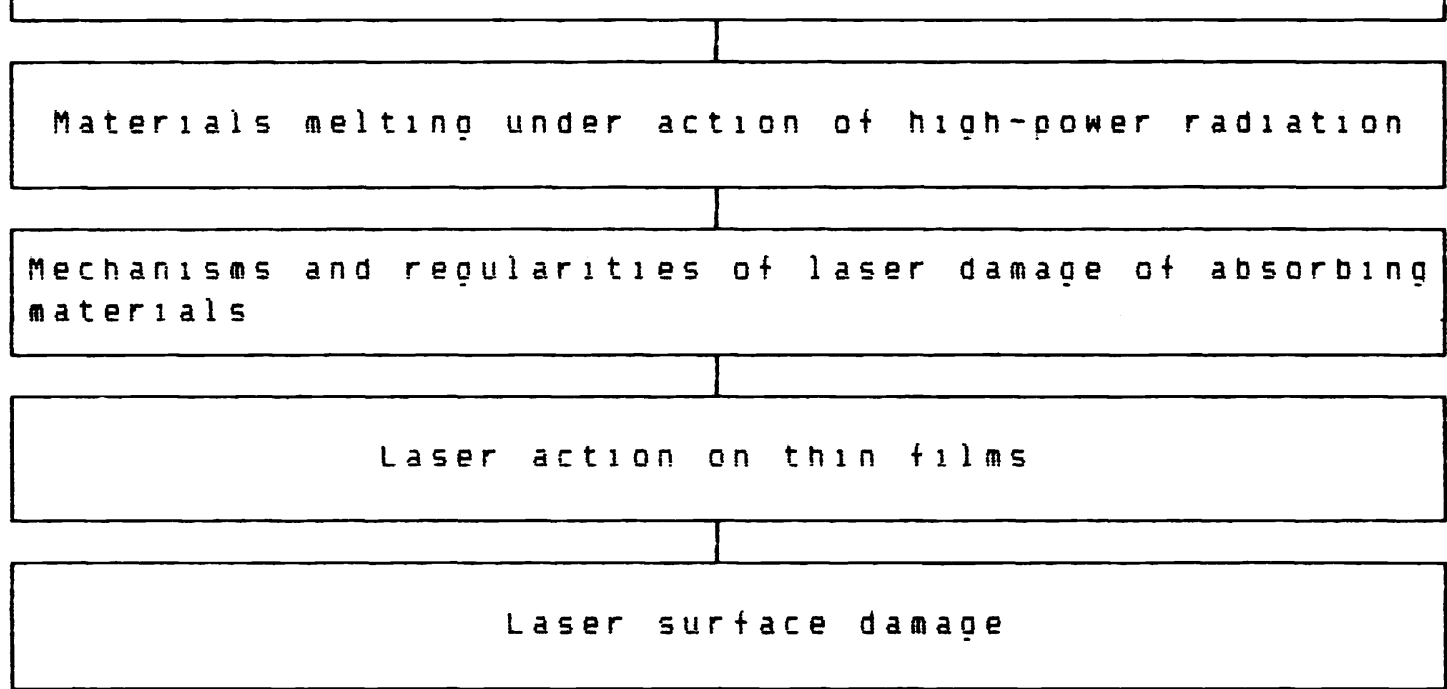

FART 2. LASER ACTION IIN PARTIALLY TRANSPARENT MEDIA

Modern conceots of laser - transoarent media interaction mechan $15 \mathrm{~ms}$

\begin{tabular}{|l|l|}
\hline Modern conceots of laser action on biological abjects \\
\hline $\begin{array}{l}\text { Nonedulibriun orocesses in matter exoosed to short oulsed } \\
\text { light action }\end{array}$
\end{tabular}


Table.3

Basic sections of the course

OPTICS OF LASER REAMS ANO LASEF EQUIPMENT

(CALCULATION AND DESIGN)

\section{FAFT 1. LASER BEAM UPTICS}

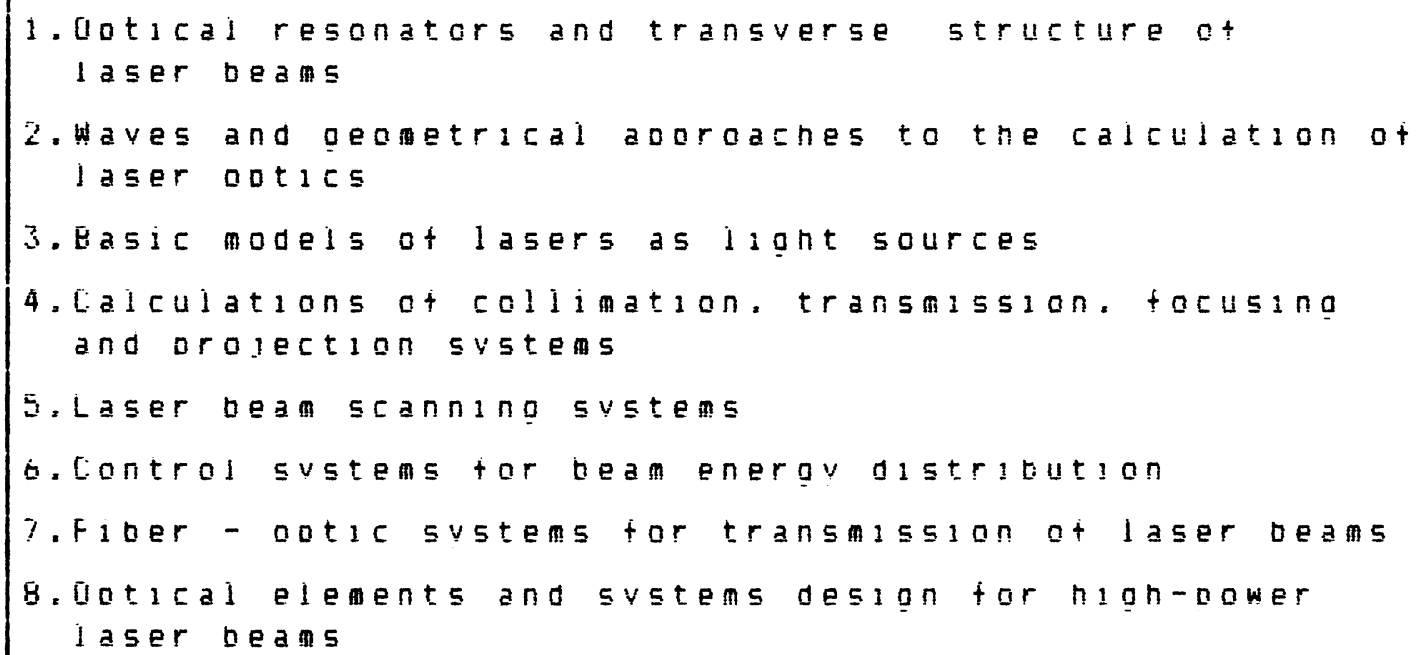

PART 2. LASER EQUIPMENT OFTICS

9. Characteristics of difterent tvoes of technological. measuring and medical eouloment

10. Basic tunctions ot ootical svstems in ILE: iliumination almino. observation. measurements etc

11 Main tvoes ot observation ootical svstem ot lLE: nonocular. binocular. television etc

12.111umination svstems: oolvenromatice monochromatis. tiber and laser ootics

13. Ditferent aimino svstems: bv the liaht beams bv the soecial marks etc

14. Comolex ootical svetems for technologv. medicine and other ourooses 


\subsection{PHYSICAL - ENGINEERING FUNDAMENTAL OF LASER TECHNOLQGY}

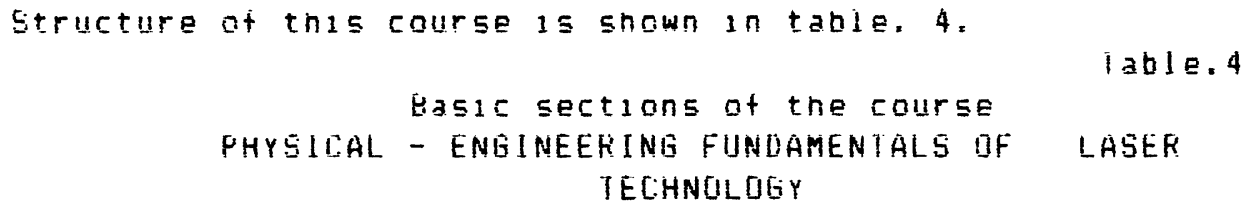

PART 1. GENERAL FRINEIPLES UF LASER TEEHNOLUEY

1. Technolooical lasers and laser radiation

2. Uotical contiouration and laser beam tormino svatems

3. Laser action on the materials

PAFT 2. LASEF TELHNULUGY FRUEESSES

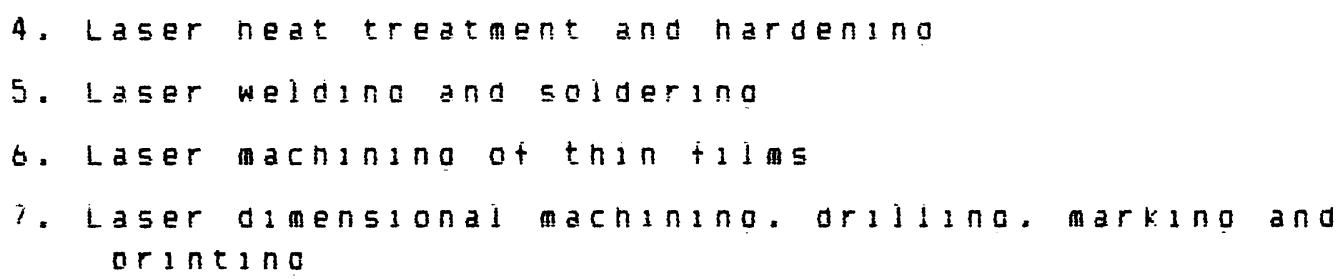

12. Laser fusion techoloovot ontical comoonents

13. Hian oower laser materials treatment

14. General orincioles ot laser tecnnnlogical eouioment

Part one is devoted to the consideration of basis knowledoe in lasers. ootics and ohvsical oroblems as aoolied to laser technologv. Basic education of laser radiation narameters which 15 most imoortant for enerov and dimension relationg for laser action threshold are alven.

Fart two is devoted to detailed consideration of different kinds of laser technological processes. such as welding. orilling. cutting. nardenino. resistors trimmino etc. Some new tooics have been recentiv oresented: laser thermo- and ohotochemistry in microejectronics laser technology in microoptics. laser-nlasma tilim deoosition. 


\subsection{LASER EQUIPMENI DESIGN. AUTOMATION AND TECHNOLOGICAL PROCESSES CONTROL.}

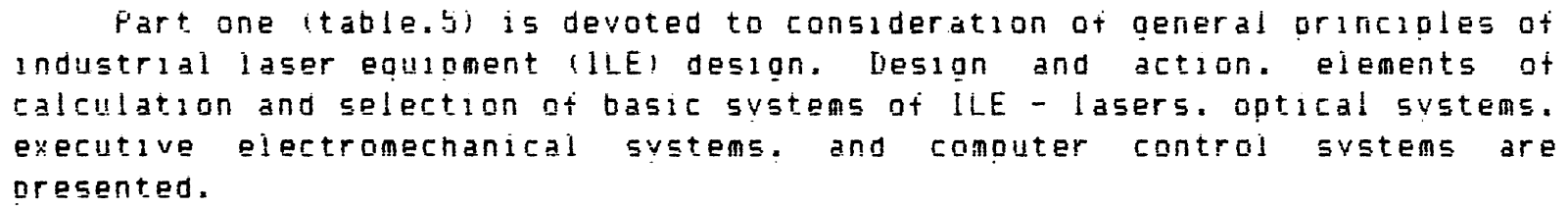

Tatie.s

Basic sections of the course

LASEF EQUIFMENT. AUTOMATION ANO

DF TECHNOLOGICAL FROCESSES CONIROL

FHRT. 1 GENEFAL FRINCIFLES OF INUUSTRIHL LASEF EQUIFMENT IILE, DESIGN, CUMPUSITIUN AND ELEMENTS

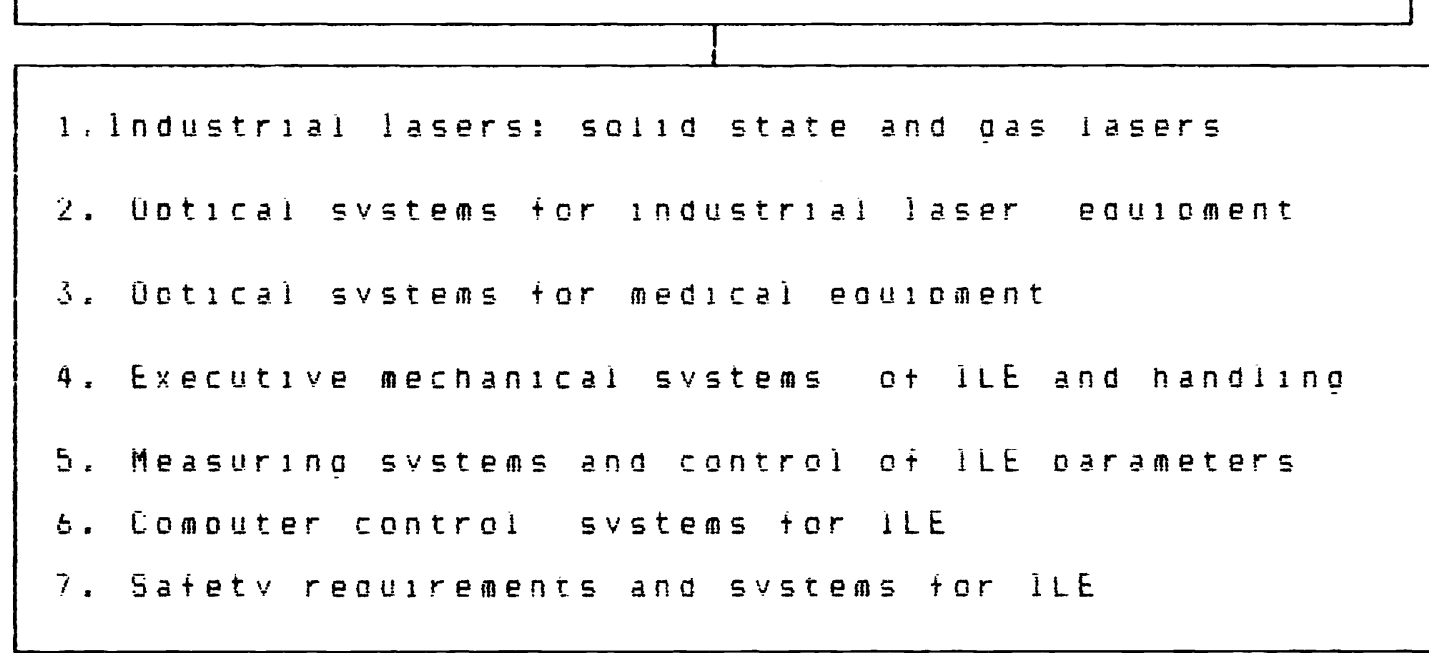

PART 2. INDUSTFIHL LASEF EUUIFMENT

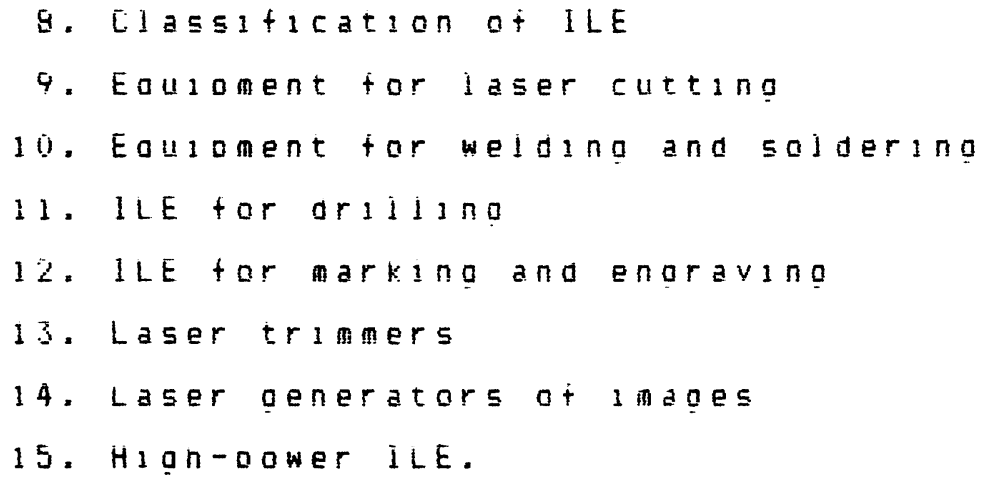


In the second oart the main tvoes of ILE are overviewed: ILE for laser heating. hardening and welding. drilling: for thick - film machining. trimming etc.

Most Dart of all of these courses B.1 - B.4 are based on the oriounal results. Which are oublished 1 n books. reviews and articles of the authors il-9i. and have no direct analogies in other hioh schools.

\section{AREAS OF PROFESSIONAL ACTIVITY OF LT CHAIR GRADUATE}

During the last tew vears aporoximatelv b - 9 students graduated from the chair annuallv and 4 - 5 post graduate students studied. some of them from Bulgaria, Hungary. Germanv. Most of them work at the industrial institutions and enterorises, some of them at the medicine clinics and LT chair:

Bood connections of LT chas with other higher schools in the USSR (Moscow State University. St. Fetersourg Technical University. Kiev Technical University, and foreign institutes - San-0ieno state University, Universitv of Arizona, Tucson: USLA, Gremen Institute of Applied Beam uptic ensure the high level of laser technology education.

\section{ACKNOWLEDGMENTS}

Authors are thankful to their colleaques or. Y. o.Berezin. Dr.

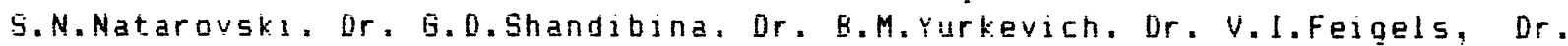
A.I.Kajdanov, M.U.Aboakoumov, Or. S.N.Belov tor helptul discussions and assistance in preparing this paper.

\section{REFERENCE}

1. U.P.Veiko, M.N.Libenson. R.A.Ialpov. A. L. Meluchev A.A. Chelnv. Laser technology. Moscow electronic pub.,1970, $112 \mathrm{p}$. (in Russian!. Russian!.

2. V.F.Veiko, M.N.Libenson, Laser processing. Leningrad, 190,1973, 1 in

3. V.P.Veika, M.N.Libenson, A.A.Chelny, F.F.Vodovatov Lasers in technology. Moscow. Energy pub, $1975,215 \mathrm{p}$ (1n Russian).

4. V.P.Veiko Laser thin - film frocessing, Leningrad. Mashinostroenie, 1986 (1n Fussian).

5. V.F.Veiko. S.M.Metev. Laser technologies in microelectronic. Sofia, Bulgaria. Academy ot Sciences pub., 1991. 365 p. (1n fiussian).

b. V.P.Veiko, S.M.Metev Laser - Assisted microtechnology. Heidelberq, Springer - Verlag, 1991 in print, English.

7. U.P.Veiko. Laser technology of microoptical components. Froceeding of SPIE, Laser surtace microprocessing, v.1352, pp. 345-352, 1989.

8. A.M.Bonch - Bruevich, M.N.Libenson. Laser-induced surface polaritons in laser damage. In book "Nonlinear surface Electromagnetic phenomena". eds. H. - E.Ponath and 6.1.Steqeman. Ansterdan, North-Holland Physics, 1991 in print, English.

9. M.N.Libenson: S.M.Minaev. Laser - stimulation of heterogeneous reactions. Froseeding of SFIE. Laser surtace microprocessing, V. 1352, pp. $149-168,1989$. 